\title{
Fight, flight or faith: A pastoral model for spiritual coping
}

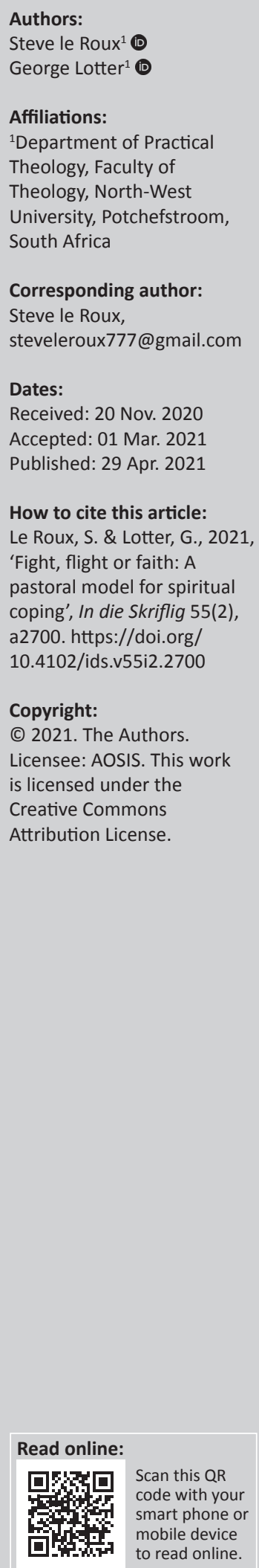

This article is dedicated to Professor Gert Breed who had an indelible influence in the expansion of Pastoral Theology in South Africa: first as minister, and second as Professor in Practical Theology. In line with Professor Breed's keen interest in the interdisciplinary approach between Theology and, for instance, Physiology and Psychology, the main aim of this article is to show how utilising spiritual coping strategies could help the Christian to cope with stress from a faith perspective. Spiritual coping was defined as an individual's ability to utilise faith in God and Judeo-Christian religious beliefs, as well as active practices to appraise, understand and effectively cope with stressful life events. A literature study was conducted on human defence response and spiritual coping to demonstrate the adverse effects of chronic defensiveness and stress. Spiritual coping was assessed from a scriptural approach to determine what biblical perspectives regarding coping, defensiveness and spirituality may be revealed. Effective coping strategies were explored to indicate how positive spiritual coping skills could be utilised as an alternative to chronic defensives. The Believe-Belong-Behave pastoral model was proposed for the utilisation of spiritual coping methods and skills that could improve psychophysiological well-being. The Believe-Belong-Behave model consists of three categories that each highlight different individual skills, corporate practices, and practical action steps, which, when applied consistently, could all function in harmony to promote psychophysiological well-being. The components of the proposed pastoral model could offer a harmonious contribution towards spiritual coping and the Christian's spiritual formation within the local church.

Contribution: This article assessed theological perspectives and biblical practices within the basic tenets of Reformed theology to identify resemblances to stress appraisal and human defensiveness throughout the historical course of Scripture. This study in Practical Theology highlighted the importance of combining a strong scriptural or theological foundation with certain practical skills to respond to stressors from a faith-in-action perspective. The proposed pastoral model showed the modern-day Christian how faith in God could be used to cope with stress more effectively.

Keywords: stress; spiritual coping; defence response; chronic defensiveness; pastoral model.

\section{Introduction}

This article addresses the question of whether faith practices and religious beliefs could show the Christian how to effectively assess and handle stress. A literature study was conducted on spiritual coping and the human defence response to highlight the adverse effects of chronic defensiveness and stress. Possible links between the fight-and-flight response and Scripture were explored. A pastoral model will be proposed to indicate how the Christian could apply positive spiritual coping skills, practices and action steps to handle stressful life events from a faith perspective. Findings from a recent study on stress-coping and the defence response (Le Roux 2020:287) will be used to propose a pastoral spiritual coping model that shows how certain religious beliefs and practices could be used to handle stressful life events. The aim of this article is thus to explore how individual skills, corporate practices and practical action steps could advance psychophysiological well-being if applied consistently and harmoniously. As Breed (2015:44) pointed out, the church is called to equip believers with the special gifts that Christ bestows on his body so that the Christian could grow in edification and maturity. The components of the proposed pastoral model could offer a harmonious contribution towards the Christian's spiritual formation within the local church.

\section{Stress-coping: An overview}

It is not the mere presence of stress that affects humans negatively, but, more so, how stress is coped with that could harmfully affect psychophysiological well-being (Braun, Foreyt \& 
Johnston 2016:235; Jackson 2012:14). This article will explore the potential benefits of utilising spiritual coping skills and practices to cope with stress (Krause et al. 2017:161). Coping and spirituality have often been studied as separate entities; yet, recent research (Koenig 2015:19; Wen 2014:1539) suggested positive links between these two concepts. Coping has been defined as 'an individual's own conscious skills, strategies, and mechanisms to deal with, solve, master, minimise or tolerate stressful situations in life' (Krägeloh et al. 2012:1139). Speed (2016:34) argued that spirituality has often been defined outside the perimeters of religion and Christianity. However, Koenig (2015:19) showed how the terms religion and spirituality have often been used interchangeably, as some of the early definitions of spirituality depicted the practice of religiously engaging in a lifestyle dedicated and surrendered to the divine (McGrath 2020; Woods 2015). Even though some prior studies on coping (Krägeloh et al. 2012:1138) focused merely on secular strategies, the positive effects of spiritual coping are being considered more frequently in stress-related studies (Sanaeinasab et al. 2020:12; Yıldırım et al. 2021:9). This motivates further investigation into the effect of spiritual coping practices on psychophysiological wellbeing. Speed (2016:34) highlighted a renewed academic and clinical interest in 'how spirituality components relate to quality of life assessments, as well as movements to incorporate spirituality into clinical practice'. Along similar lines, this article will focus on the contemporary understanding of spiritual coping, as it relates to the application of Judeo-Christian religious beliefs, thought processes, behavioural efforts and practices to combat 'stressful demands that may exceed a person's resources' (Gitay 2015:31). Furthermore, a pastoral model will be proposed to suggest 'how positive spiritual coping skills could be applied to improve psychophysiological wellbeing' (Le Roux 2020:287).

\section{Stress-coping defined}

The term stress is defined as 'a transactional process arising from environmental demands' (Jackson 2012:14) and 'the perception of an aversive event (i.e. physical, mental, or emotional) that threatens a person's psychophysiological well-being' (Braun et al. 2016:235). Merriam-Webster (2017) shows that cope is used to denote 'dealing with and attempting to overcome difficulties'. The term cope 'derived from the Latin word colpus - a blow, via the French word couper - to cut or to alter' (Le Roux 2020:16), and 'its primary meaning of hitting or cutting then produced secondary senses of contending with and finally overcoming' (Keil 2004:660). In conjunction, stress-coping is defined as 'an individual's ability to adjust cognitive, attitudinal, emotional, and behavioural processes' (Braun et al. 2016:235) when a perceived stressor exceeds a person's capacity and ability to handle the situation effectively. Stress-coping thus determines whether a perceived stressor could either be dealt with effectively, or whether such a stressor threatens psychophysiological well-being.

\section{Defence response: Fight-or-flight}

Stress forms an unavoidable part of human life (Braun et al. 2016:235; Jackson 2012:14). As there will always be some traces of stress in the life of the Christian, the question beckons how stress could be coped with effectively. The human defence response mechanism has been described as 'the automatic appraisal of potential stressors, which sets in motion some hardwired neurological and psychological processes for the primary goal of protection and selfpreservation' (Kronström et al. 2009:690). The defence mechanism is automatically activated during stress appraisal, as 'the brain plays an intricate role in coping since it is the organ that mediates stress appraisal' (McEwen \& Gianaros 2010:210). The neurological wiring of the brain causes an automatic underlying appraisal of new scenarios and events to identify any potential harm or threats. (Malan \& Malan 2016:497).

According to Geertz (2010:316), the 'complexity within which our minds develop and grow must be in the forefront of any general theory of religion'. Le Roux (2020) showed how:

$[P]$ erceived changes in the environment inform the senses with downstream signalling in certain cerebral cortex areas, which sets in motion cognition of the challenge/stressor as a challenge or a threat, defined as stress appraisal. (p. 29)

The defence response then 'stimulates sympathetic activity to increase heart rate and blood pressure to prepare the individual for a fight-or-flight situation' (Everly \& Lating 2019). During stress appraisal, the body is wired to fend off (fight response) or escape (flight response) any threat that is perceived as potentially harmful. In contrast to a chronic fight-or-flight response, the Christian's ability to use this adaptive energy more sparingly during stress appraisal (faith response) 'could lead to better health, greater happiness, and even longevity' (Jackson 2012:14).

\section{Chronic defensiveness: Adverse effects}

Chronic defensiveness and stress overload have proven to endanger a person's well-being (Koenig 2015:20; Malan \& Malan 2016:497). The inability to effectively cope with frequent stressors has negative effects on various major body systems with measurable health repercussions, because bodies 'possess a limited amount of energy to adapt to stressful situations' (Jackson 2012:14). An essential feature of effective stress coping is 'a sequence where physiological systems are turned on by a perceived stressor and turned off after cessation of the stressor' (Malan \& Malan 2016:497). During chronic defensiveness, these physiological systems are in a state of constant alert, which eventually depletes the mind and body's adaption energy. It has, however, been shown (Koenig 2015:23) that engaging in certain religious activities such as prayer and worship could decrease the harmful effects of chronic fight-or-flight activation (Anderson \& Nunnelley 2016:635; Michael Liedke 2018:6). 


\section{Spiritual coping: Recent findings}

Recent studies inferred that certain spiritual practices could positively affect psychophysiological well-being and emotional stability (Bonelli \& Koenig 2013:657; Dalmida et al. 2013:57; Weber \& Pargament 2014:358). In various studies (Balbuena, Baetz \& Bowen 2013:231; Barton et al. 2013:56; Sanaeinasab et al. 2020:12) sustained religious involvement and frequent worship attendance helped reduced major depression symptoms. Krumrei, Pirutinsky and Rosmarin (2013:335) suggested that 'latent core beliefs about the Divine encouraged the use of active coping strategies during times of distress'. Furthermore, Gomes et al. (2013:36) showed that 'spirituality was found to be a strong protective factor against negative coping strategies, such as substance abuse'. Additional studies (Bonelli \& Koenig 2013:657; Jordan et al. 2014:418; Weber \& Pargament 2014:358) suggested that frequent religious involvement promoted the consistent application of spiritual coping methods 'as practical strategies to manage stressors such as uncertainty, fear, pain, disability, discouragement, loss of control, or loss of hope' (Le Roux 2020:68). Similar studies (Hayward et al. 2012:1; Hybels et al. 2014:680) showed how to identify and measure the effectiveness of utilising spiritual coping tactics. The abovementioned findings were relevant to this current article's focus on spiritual coping, because spirituality has been related to 'greater psychophysiological well-being and better medical health outcomes among respective study groups' (Koenig 2015:23).

\section{Spiritual coping: A faith response to stress}

Le Roux (2020:287) argued that 'spirituality and religious beliefs provide a sense of meaning and purpose during difficult life circumstances'. Spirituality, founded on faith in God, typically encourages a positive worldview that brings a sense of hope amid trouble. Recent findings showed (Weber \& Pargament 2014:358; Yıldırım et al. 2021:9) how certain religious practices could be used to handle common stressors like disappointments, anxiety, hopelessness and discouragement. Ellison et al. (2014:208) suggested that people who lack the 'comfort of strong faith or the emotional support of a religious community' do not seem to cope as well with common life stressors as the Christian who is actively involved in a religious organisation or faith community. The uniqueness of spiritual coping is the notion that, by God's grace, Christ has provided a universal opportunity to any human being to practise faith in the divine. Thus, the spiritual coping methods and skills, proposed in this article, are religious practices that could be utilised by any human being, regardless of race, creed, colour or gender (Koenig 2015:19; Wen 2014:1539). In summary, spiritual coping refers to actively 'dealing with stress from a biblical perspective and using faith in Jesus Christ, coupled with religious practices and church involvement, to handle stressful life events more effectively' (Le Roux 2020:10) as will be described in this article's proposed spiritual coping model.

\section{Stress-coping and defence response in Scripture}

From a Practical Theology viewpoint, the findings that emerged from a recent study on stress-coping and the defence response (Le Roux 2020:287), combined with the seemingly positive effects of spiritual coping, needed to be explored in light of Scripture (De Klerk, De Wet \& Pieterse 2012:5). By using 'the narrative of Scripture (history) and the message and application of Scripture (revelation)' (Van der Walt 2007), links between the human defence response and Psalm 55 were explored, as David's reaction to stress seems remarkably similar to a fight-or-flight response. However, it was important to first examine scriptural themes and patterns regarding human defensiveness, revealed as early as the creation narrative.

\section{Stress appraisal and defence response in the Garden of Eden}

Pretorius (2011) suggested that the biblical account of the events in Eden showed:

$[T]$ he characters and events that resulted in the fall of mankind were not mere mythological anecdotes, but concrete descriptions of factual events and characters, which had a significant impact on the entire human race. (p. 161)

Stress could thus be understood as a result of humankind's disconnection from their divine Creator because of their sinful actions in Eden (Smither 2014:2). Lioy (2010:25) described the effects of humanity's original sin (Gn 3:7-10) as 'a sense of nakedness, a sense of fear, and a sense of avoidance'. Le Roux (2020:204) suggested that the 'opening of Adam and Eve's eyes could possibly be classified as a form of stress appraisal'. Lloyd-Jones (2009) recounted the freedom that humanity experienced in Eden where Adam and Eve's initial state of nakedness did not provoke any sense of shame (Gn 2:25). However, as a result of their disobedience, their nakedness became 'extremely shameful' (Kim 2010:226).

Their naked state was suddenly perceived as a threat and 'their hurried attempt to cover themselves with fig leaves could be paralleled with avoidance coping' (Le Roux 2020:205). A second example of stress appraisal in Eden was when God approached Adam with the question, 'Where are you?' (Gn 3:9 - New International Version [NIV]). God's voice, an outward stimulus, was now perceived by his created being as a threat, resulting in inner turmoil (Collins 2010:156). Lloyd-Jones (2009) described Genesis 3 as 'humanity's first introduction to the sense of fear'. Their haste reaction to hide from God parallels avoidance coping (Le Roux 2020:204). Kim (2010:227) identified an additional negative coping default in Eden, namely blame-shifting. As God drew near to his beloved created beings who were now in distress, they defaulted to avoidance tactics instead of facing the consequences of their choices and actions (Gn 3:12-13). The sequence of events after the fall-of-mankind could indicate the origin of the human fight-or-flight response. The traces of stress appraisal and defensiveness in Eden were kept in 
consideration during the formulation of the proposed coping model. Le Roux (2020) showed the correlation between stress appraisal and Adam and Eve's reaction to sin:

Because of a distorted perspective caused by $\sin$ and disobedience, Adam and Eve perceived both their nakedness and God's presence as threats (stress appraisal). They swiftly tried to avoid both perceived threats; first, by covering themselves with fig leaves (avoidance coping), and second, by hiding from God (avoidance coping / DefS [defence strategy] flight response). When God confronted them about their sin, they both resorted to blame-shifting as a form of self-preservation (avoidance coping / DefS - fight response). (p. 205)

\section{Stress appraisal and defence response in fallen humanity}

Collins (2010:156) showed that original sin had a devastating impact on relationships: 'One of the major effects of that corruption was social: Adam against Eve, Cain against Abel, Lamech the bigamist against everyone.' Adam and Eve's rebellion negatively impacted their first offspring, Cain and Abel (Gn 4:1-2). Cain's reaction after God rejected his offering shows traces of stress-coping and human defensiveness, as he suddenly viewed God and Abel as threats (stress appraisal) (Gn 4:5). Cain distorted threat perceptions had psychophysiological effects, as his countenance became downcast (Gn 4:6). Cain defaulted to negative coping strategies when he isolated, assaulted and murdered Abel (DefS - fight response). He continued down this path of negative coping when he resorted to denial before God (avoidance coping [DefS - fight response]). The consequences of Cain's rebellion were far-reaching, because he became 'adversely affected in those areas that have previously been singled out for blessing; fertility (Gen 1:28), relationships (Gen 1:28-29), and rest from labour (Gen 2:3)' (McKeown 2008). Le Roux (2020:207) showed how the tragic Genesis account of the first family feud demonstrated how unrestrained defensiveness could cause a stressful situation to escalate and bring about disastrous outcomes'. The Eden drama shows that one of the main consequences of sin was humanity's separation from God (McKeown 2008). The family feud between Cain and Abel shows how the initial separation from God ultimately lead to separation among people. Paynter (2019) suggested that the great deal of turmoil, wars and genocides recorded in the Old Testament highlights the ongoing negative effects of humanity's relational decay. This relational dilemma becomes further evident in the New Testament. When Jesus Christ took on humanity to redeem fallen humanity, he, too, was confronted with conflicts and various life-threatening altercations (Jn 7:39; 12:16, 23; 13:31; Bruner 2012). It is of value to note that, during the Garden of Gethsemane arrest (Jn 18), Christ's disciples defaulted to fight-or-flight coping methods. When the soldiers showed up to arrest Jesus (Jn 18:3), the disciples perceived their close ties to Jesus as a threat (stress appraisal - perceived threat). Most of the disciples resorted to an impulsive escape response by running away (Mt 26:56) (avoidance coping [DefS - flight response]). Peter, however, chose a confrontational response when he pulled out his sword (Jn 18:10) (DefS - fight response). Peter's consequent threefold denial of Christ was an additional form of defensiveness (Jn 18:26-27) (avoidance coping). The numerous accounts of conflicts and relational turmoil recorded in Old and New Testament narratives were considered during the formulation of a positive spiritual coping model (Le Roux 2020:222).

\section{Stress appraisal and defence response in Psalm 55}

The stress-coping techniques of King David, as described in Psalm 55, were analysed to demonstrate how a faith response could be applied to handle stress. Psalm 55 provides a clear scriptural example of spiritual coping. David's initial reaction to trouble parallels a fight-or-flight response. However, he eventually resorted to a faith response that strongly simulates spiritual coping. Mays (2011) described the lament in Psalm 55 as a 'moving prayer for help in a very hostile environment'. David's anguish was fuelled by the lawlessness of his enemies (Ps 55:1-9), but he also experienced personal betrayal (Ps 55:12-14, 20-21). Botha (2017:118) suggested that these stressors caused mental turmoil, high agitation and anger (Ps 55:45) (fight response), which caused a yearning to escape the threat (Ps 55:6-8) (fight response). However, after David considered his fight-or-flight options he chose to utilise the spiritual coping skills of prayer and trust in God (faith response):

But I will call on God, and the LORD will rescue me. Morning, noon, and night I cry out in my distress, and the LORD hears my voice. He ransoms me and keeps me safe from the battle waged against me, though many still oppose me. He rescues me unharmed from the battle waged against me, even though many oppose me. Give your burdens to the LORD, and he will take care of you. He will not permit the godly to slip and fall. (Ps 55:16-18, 22 - NIV)

The various traces of stress appraisal, fight-or-flight response and spiritual coping resemblances described in Psalm 55 are illustrated in Table 1 (Le Roux 2020:209).

David's first reaction to stress is turning to God in prayer (spiritual coping). He remains fully aware of the threat his enemies pose (stress appraisal) as he describes some spontaneous physical changes in his body, including elevated

TABLE 1: Stress appraisal and chronic defensiveness (DefS) in Psalm 55.

\begin{tabular}{llll}
\hline Passage & Action or reaction & Coping style similarities & Effect \\
\hline Psalm 55:1 & $\begin{array}{l}\text { David prays to ask } \\
\text { God for help }\end{array}$ & Spiritual coping & Positive \\
Psalm 55:2-3 & $\begin{array}{l}\text { David recognises } \\
\text { threats against him }\end{array}$ & $\begin{array}{l}\text { Stress appraisal - } \\
\text { Perceived threat }\end{array}$ & Negative \\
Psalm 55:4 & $\begin{array}{l}\text { David senses anguish } \\
\text { in his heart }\end{array}$ & $\begin{array}{l}\text { DefS - Elevated heart } \\
\text { rate \& blood pressure }\end{array}$ & Negative \\
Psalm 55:5 & $\begin{array}{l}\text { David trembles and } \\
\text { feels overwhelmed }\end{array}$ & $\begin{array}{l}\text { Perception - loss of } \\
\text { control }\end{array}$ & Negative \\
Psalm 55:6-8 & $\begin{array}{l}\text { David desires to } \\
\text { escape and flee away }\end{array}$ & $\begin{array}{l}\text { Avoidance coping / } \\
\text { DefS - Flight response }\end{array}$ & Negative \\
Psalm 55:16-18 $\begin{array}{l}\text { David calls out to } \\
\text { God in his distress }\end{array}$ & $\begin{array}{l}\text { Spiritual coping } \\
\text { David casts his care } \\
\text { on the Lord }\end{array}$ & Spiritual coping & Positive \\
\hline Psalm 55:22 & Positive \\
\hline
\end{tabular}

Source: Adapted from Le Roux, S., 2020, 'The body metaphor and spiritual coping within a South African cohort: A pastoral approach', PhD dissertation, Faculty of Theology, NorthWest University. 
heart rate (DefS - fight response). He then experiences a sense of being overwhelmed (loss of control), and he expresses his desire to flee (avoidance coping [DefS - flight response]). However, instead of fighting or fleeing, David turned to prayer again (spiritual coping). David's encouragement to cast our cares onto the Lord amid distress is often reiterated in Scripture (cf. Mt 11:28; Phlp 4:6; 1 Pt 5:7). The Psalms frequently uses the term selah which suggests a pause at the end of a passage (Schader 2013:124). Le Roux (2020:210) suggested that selah encourages the reader 'to pause, reflect, and contemplate the meaning of a particular phrase or passage'.

After pausing to contemplate a fight-or-flight response, David chose a faith response instead.

\section{Spiritual coping: Fight, flight, or faith?}

It is important for the Christian to understand that the human defence response mechanism is innate (Kronström et al. 2009:690; McEwen \& Gianaros 2010:210). Thus, during stress appraisal, it is normal to automatically consider potential fight-or-flight options. However, this article shows the Christian that utilising certain positive spiritual coping skills will encourage a faith response to stress that promotes psychophysiological well-being.

\section{A proposed pastoral model for utilising positive spiritual coping skills Background}

Le Roux et al. (2018) assessed:

[T] he relationship between hypertension, depression, and cultural coping strategies in a South African teacher cohort to determine whether applying spiritual coping strategies showed beneficial effects on blood pressure and psychophysiological well-being. (p. 367)

Many cohort teachers reported alarmingly high levels of hypertension as a direct result of chronic stress and increased defensiveness. This particular study of Le Roux et al. (2018:372) concluded, 'during counselling of depressed patients with hypertension, the salutary effects of support and spiritual coping may be of great importance'. Effective coping strategies were further explored to identify how the Christian could be equipped to handle chronic stress and acute depression from a faith perspective.

\section{Introduction of the Believe-Belong-Behave model}

The Believe-Belong-Behave model for applying positive spiritual coping skills to handle stress consists of three categories. The Believe category focuses on 'the individual skills that could be developed through a Christian's belief in God' (Le Roux 2020:226). The Belong category emphasises 'the corporate practices that a Christian could find by belonging to the Body of Christ, as expressed in the local church' (Le Roux 2020:226). The Behave category suggests 'practical action steps that can be taken when confronted
TABLE 2: The Believe-Belong-Behave model.

\begin{tabular}{lll}
\hline Believe & Belong & Behave \\
\hline Individual skills: & Corporate practices: & Action steps: \\
1. Faith in God & 1. Social support & 1. Pray first \\
2. Dialogue with God & 2. Corporate worship & 2. Take a Selah-moment \\
3. Word of God & 3. Discipleship training & 3. Choose faith over fear \\
4. Hope in God & 4. Missional servanthood & 4. Think optimistically \\
5. Purpose from God & 5. Pastoral care & 5. Gain perspective \\
\hline
\end{tabular}

Source: Adapted from Le Roux, S., 2020, 'The body metaphor and spiritual coping within a South African cohort: A pastoral approach', PhD dissertation, Faculty of Theology, NorthWest University.

with perceived stressors and threats' (Le Roux 2020:226). Each of the categorised skills, practices and action steps will be further defined to show how each component could help the Christian handle stress from a faith perspective. This model proposes that internal faith in God (believe) combined with the connectedness provided by a faith community (belong), could promote habitual positive reactions (behave). The Believe-Belong-Behave model is schematically illustrated in Table 2 (Le Roux 2020:225):

\section{Description of the Believe-Belong-Behave model}

The 15 components of the proposed Believe-Belong-Behave model have been further defined to contribute to the Christian's utilisation of positive spiritual coping skills to handle stress:

\section{'Believe' category - Individual skills Skill \#1: Faith in God:}

[T] he Christian's ability to grow in personal faith in God as Heavenly Father, to confidently trust in the redemptive work of Jesus Christ as the Son of God, and to be empowered by the Holy Spirit. (Le Roux 2020:229)

As fear appears to be a direct consequence of original sin, the Christian can turn to faith in Christ's redemptive work to reduce fear. Adam, Eve and Cain's fear-based reactions strategies showed the detrimental effects of not having faith in God. In contrast, King David showed faith in God during times of trouble. The church should encourage the Christian to grow in faith through salvation, prayer, repentance, forgiveness, Bible study and active involvement in a faith community (Jones 2010).

\section{Skill \#2: Dialogue with God:}

[T] he ability to approach God through Christ as Saviour and Mediator to engage in a frequent and ongoing conversation with God through personal prayer, worship, reflection, and discernment of God's voice through the awareness of the Holy Spirit's indwelling presence. (Le Roux 2020:229)

Original sin distorted Adam and Eve's ability to communicate with God, and Cain perceived God's actions as a threat. In contrast, King David immediately turned to prayer and supplication when he sensed trouble. The church should encourage the Christian to develop a conversational prayer life through frequent dialogue with God when facing difficulties (Jones 2010). 


\section{Skill \#3: Word of God:}

[T] he ability to habitually study the Word of God for inspiration, encouragement, strength, correction and direction, through frequent times of personal Bible study, devotion and reflection; thus, allowing Scripture to guide thoughts, words and action. (Le Roux 2020:229)

Scripture's detailed description of Adam, Eve, and Cain's fear response contrasted with King David's faith response makes the Bible relevant to modern-day stress coping. The church should encourage the Christian to study and apply scriptural wisdom and guidance in learning how to react to impending threats (Jones 2010).

Skill \#4: Hope in God: This skill refers to 'the ability to gain hope amid distress by establishing a confident expectation through trust in God's faithfulness, propensity and preparedness to intervene in a divine manner' (Le Roux 2020:229). Adam and Eve's self-consciousness and Cain's downcast countenance brought about a sense of hopelessness. In contrast, King David expressed a confident hope in God's ability to rescue him. The church should encourage the Christian to have hope in God amid troubled times by developing a confident expectation that God will always be present to comfort, guide and intervene (Jones 2010).

\section{Skill \#5: Purpose from God:}

[T]he ability to use spiritual gifts, natural abilities, and acquired competence to passionately pursue a sense of God-given purpose, ministry, and vocation by supporting organizations involved in the betterment and upliftment of people and the enhancement of a community. (Le Roux 2020:229)

After the fall, Adam and Eve lost their God-given sense of purpose when they became subject to the curse of toil and sweat. Cain's distorted relationship with his family caused him to labour in toil. In contrast, King David, anointed by God to rule over Israel, trusted that God would enable him to fulfil his divine calling. The church should encourage the Christian to develop a sense of purpose from God by identifying natural abilities, acquired skills and spiritual gifts that could be used to further God's kingdom purpose (Jones 2010).

\section{'Belong' category - Corporate practices}

Practice \#1: Social support: This practice refers to 'a willingness to seek care and encouragement through engagement in supportive social networks, as can be found in the local church or community of believers' (Le Roux 2020:230). Original sin not only distorted humanity's relationship with God, but it also affected human relationships in devastating ways. Adam and Eve's sin caused relational decay when they resorted to blame-shifting. Cain's unrestrained defensiveness caused further relational decay in the first family. King David was betrayed by a close friend. People often rely on family and friends for support; yet, past relational trauma could damper someone's willingness to seek social support. The church should encourage the Christian to seek social support and godly counsel within the Body of Christ during times of distress (Minatrea 2012).

\section{Practice \#2: Corporate worship:}

$[A]$ willingness to engage in activities that promote an awareness of God's omnipotence, omnipresence, omniscience, and omnibenevolence through frequent attendance of corporate gatherings, as can be found in church worship services and related assemblies and events. (Le Roux 2020:230)

Sin caused Adam, Eve and Cain to grow distant from God. In contrast, King David chose to draw near to God through prayer and worship. As engaging in the spiritual practice of corporate worship have shown neurophysiological benefits, the church should encourage the Christian to focus on Christ's overcoming power by engaging in corporate worship amid times of distress (Minatrea 2012).

\section{Practice \#3: Discipleship training:}

$[A]$ willingness to engage in ministry and vocational training through initiatives that identify and develop spiritual gifts, natural abilities, and acquired skills, as can be found in various discipleship ministries and programmes of the local church. (Le Roux 2020:230)

Adam, Eve and Cain were reluctant to repent and take responsibility for their actions. In contrast, King David was quick to admit his failures and dependency on God's grace and mercy. The church should encourage the Christian to engage in discipleship-training programmes that promote salvation, prayer, repentance, forgiveness, Bible study, spiritual growth and active involvement in a faith community (Minatrea 2012).

\section{Practice \#4: Missional servanthood:}

$[A]$ willingness to support and engage in outreach programmes to spread the Gospel and serve the hurting, helpless, and underprivileged through acts of kindness and sacrificial empathy, as can be found in local and global missional initiatives of churches and humanitarian organizations. (Le Roux 2020:230)

The fall of humanity brought about a deep sense of guilt, fear and isolation. The ripple effects of sin are still affecting modern-day humanity in negative ways. The church should encourage the Christian to engage in missional servanthood by helping people in need, reaching the lost and proclaiming the gospel message of redemption through Christ (Minatrea 2012).

\section{Practice \#5: Pastoral care:}

$[A]$ willingness to seek counsel and care during times of distress and depression, as can be found in the form of Christian counselling, pastoral care, congregational support, and church benevolence, as well as encouraging others in need. (Le Roux 2020:230)

Driven by an intense sense of shame, Adam and Eve tried to cover themselves with fig leaves. In contrast, King David cried out to God to cover his shame. As the sense of guilt, shame, fear and isolation brought about by humanity's original sin is still prevalent in modern-day humanity, pastoral care should show the Christian that avoidance and 
denial fuel shame, while repentance and forgiveness in Christ remove shame. The church should encourage the Christian to seek pastoral care that deals with past trauma and promotes healthy relationship skills (Minatrea 2012).

\section{'Behave' category - Action steps Step \#1: Pray First:}

[A] proactive decision to immediately pray to God as soon as a threat or stressor has been detected, in order to find inner peace and divine guidance that could promote an appropriate faithinspired response on an ongoing basis. (Le Roux 2020:231)

Because stress appraisal happens subconsciously to set in motion a fight-or-flight response, praying first denotes proactively seeking God's guidance before determining whether to alleviate or escape a stressor. Neither Adam and Eve, nor Cain prayed after they sinned. Instead, they tried to solve their problems independently. In contrast, King David prayed to God first. As engaging in habitual prayer has shown neurophysiological benefits, the church should encourage the Christian to proactively turn to prayer first to find inner peace and guidance from God before reacting to trouble (Woods 2015).

\section{Step \#2: Take a Selah-moment:}

[A] proactive decision to pause whenever a threat or stressor has been detected, in order to reflect on God's omnipotence, omnipresence, omniscience, and omnibenevolence, before choosing an appropriate faith-inspired response. (Le Roux 2020:231)

Adam, Eve and Cain reacted impulsively without taking time to contemplate their possible options and without waiting on divine guidance. Their immediate fight-or-flight response affected them in various negative ways. Even though King David contemplated a potential fight-or-flight response, he took the time to seek direction from God. The term selah in the Psalms encourages a reflective pause. The church should encourage the Christian not to react to stressors in swift and aggressive defensiveness. Taking a Selah-moment means proactively taking time to pause, breathe, calm down and seek godly guidance on how to react (Woods 2015).

\section{Step \#3: Choose faith over fear:}

$[A]$ proactive decision to apply faith in God's omnipotence, omnipresence, omniscience, and omnibenevolence amid stress appraisal, in order to counter any fear-driven instinctive fightor-flight reactions, by choosing an appropriate faith-inspired response instead. (Le Roux 2020:231)

Adam, Eve and Cain reacted in fearful ways that caused them to resort to a fight-or-flight response. Even though King David recognised an intense sense of fear in his heart, he chose to turn to faith in God as a coping mechanism. The church should encourage the Christian to choose stress responses that are inspired by faith instead of driven by fear (Woods 2015).

\section{Step \#4: Think optimistically:}

$[A]$ proactive decision to remain hopeful after a threat or stressor has been detected, by thinking faith-inspired and optimistic thoughts about potential solutions and positive outcomes, instead of defaulting to fear-driven negative thoughts of hopelessness and helplessness. (Le Roux 2020:231)

The vigorous mental strain caused by stress and anxiety negatively affects psychophysiological well-being. Adam and Eve believed the lies of the serpent by doubting God's goodness. Cain's thoughts were driven by anger and resentment. These negative thoughts brought about negative actions and reactions. King David described how the threats against him caused mental turmoil; yet, he chose to focus his thoughts on God's ability to ransom him. The church should encourage the Christian to think optimistically during times of trouble by focussing on the true peace, hope, and security that Christ brings (Woods 2015).

\section{Step \#5: Gain perspective:}

$[A]$ proactive decision to gain divine perspective after a threat or stressor has been detected, by considering spiritual boundaries that could promote healthy responses, by contemplating various scenarios that could promote positive outcomes, and by looking at current circumstances from an eternal life viewpoint and faithinspired frame of mind. (Le Roux 2020:231)

Humanity's original sin resulted in unrestrained defensiveness that became evident throughout biblical history. However, King David showed that a godly perspective offers alternative ways to handle problems more effectively. The church should encourage the Christian to gain divine perspective by realising that worldly trials and troubles are temporary, but faith in Jesus Christ provides an inner peace that surpasses all shortterm circumstances. Because Christ promised complete victory, everlasting freedom and eternal peace for all those who receive salvation, the church should also encourage an eternal life perspective (Woods 2015).

\section{Conclusion}

This study on spiritual coping revealed that innate defensiveness during stress appraisal activates an automatic fight-or-flight response. However, through the overcoming power of Christ, it is possible for the Christian to find inner peace and hope that motivates a faith response to handle stress. The Belief-Belong-Behave model was designed as a pastoral guideline that shows how the Christian could use certain biblical skills, practices and action steps as spiritual coping mechanisms. The culmination of the findings that emerged from this study on stress-coping and the defence response in Scripture were used to propose a coherent spiritual coping model that suggested ways in which the Christian could use spirituality to cope with stress. When applied consistently within a religious community, these spiritual coping skills could promote psychophysiological well-being. This pastoral model also contributes towards a strong foundation for the Christian's spiritual growth, stability and maturity within a faith community. 


\section{Acknowledgements}

The authors would like to acknowledge Professor Leoné Malan for her role as advisor of the original study on spiritual coping and the body metaphor in Scripture (Le Roux 2020), which provided the parameters within which the BelieveBelong-Behave model was developed. Prof. Malan designed the first brain-heart prospective cohort study in Sub-Saharan Africa in 2008 and, as principal investigator, she received an international award for project design excellence. She has also spearheaded the development of a clinical screening tool for preventive medicine to phenotype chronic emotional stress to improve preventive health care.

\section{Competing interests}

The authors declare that they have no financial or personal relationships that may have inappropriately influenced them in writing this article.

\section{Authors' contributions}

S.L.R. conducted an extensive literature study on stress, chronic defensiveness and spiritual coping. S.L.R. assessed spiritual coping from a pastoral approach, and determined what scriptural perspectives regarding coping and spirituality may be revealed. S.L.R. then designed and proposed a pastoral model to apply spiritual coping methods and skills. G.L. supervised the findings of this study and helped to develop the theoretical framework of this article. G.L. further reviewed and edited the writing of this article.

\section{Ethical considerations}

This article followed all ethical standards for research without direct contact with human or animal subjects.

\section{Funding information}

This research received no specific grant from any funding agency in the public, commercial or not-for-profit sectors.

\section{Data availability}

The authors confirm that the data supporting the findings of this study are available within the article.

\section{Disclaimer}

The views and opinions expressed in this article are those of the authors and do not necessarily reflect the official policy or position of any affiliated agency of the authors.

\section{References}

Anderson, J.W. \& Nunnelley, P.A., 2016, 'Private prayer associations with depression, anxiety and other health conditions: An analytical review of clinical studies', Postgraduate Medicine 128(7), 635-641. https://doi.org/10.1080/00325481.201 6.1209962

Balbuena, L., Baetz, M. \& Bowen, R., 2013, 'Religious attendance, spirituality, and major depression in Canada: A 14-year follow-up study', The Canadian Journal of Psychiatry 58(4), 225-232. https://doi.org/10.1177/070674371305800408
Barton, Y.A., Miller, L., Wickramaratne, P., Gameroff, M.J. \& Weissman, M.M., 2013, 'Religious attendance and social adjustment as protective against depression: A 10-year prospective study', Journal of Affective Disorders 146(1), 53-57. https:// doi.org/10.1016/j.jad.2012.08.037

Bonelli, R.M. \& Koenig, H.G., 2013, 'Mental disorders, religion and spirituality 1990 to 2010: A systematic evidence-based review', Journal of Religion and Health 52(2), 657-673. https://doi.org/10.1007/s10943-013-9691-4

Botha, P.J., 2017, 'Psalm 55 interpreted in view of its textual, metatextual and intertextual connections', Scandinavian Journal of the Old Testament 31(1), 118-141. https://doi.org/10.1080/09018328.2017.1301642

Braun, C., Foreyt, J.P. \& Johnston, C.A., 2016, 'Stress: A core lifestyle issue', American Journal of Lifestyle Medicine 10(4), 235-238. https://doi.org/10.1177/155982 7616642400

Breed, G., 2015, 'Ministry to the congregation according to the letter to the Ephesians', Acta Theologica 35(1), 37-58. https://doi.org/10.4314/actat.v35i1.3

Bruner, F.D., 2012, The gospel of John: A commentary, Wm. B. Eerdmans Publishing, Grand Rapids, MI.

Collins, C.J., 2010, 'Adam and Eve as historical people, and why it matters', Perspectives on Science \& Christian Faith 62(3), 147-165.

Dalmida, S.G., Koenig, H.G., Holstad, M.M. \& Wirani, M.M., 2013, 'The psychological well-being of people living with HIV/AIDS and the role of religious coping and social support', The International Journal of Psychiatry in Medicine 46(1), 57-83. https://doi.org/10.2190/PM.46.1.e

De Klerk, B.J., De Wet, F.W. \& Pieterse, H.J., 2012, 'The necessity of taking account of meta-theoretical assumptions in the scientific approach and task envisaged for practical theology', In die Skriflig 46(2), 1-11. https://doi.org/10.4102/ids. v46i 2.59

Ellison, C.G., Bradshaw, M., Flannelly, K.J. \& Galek, K.C., 2014, 'Prayer, attachment to God, and symptoms of anxiety-related disorders among US adults', Sociology of Religion 75(2), 208-233. https://doi.org/10.1093/socrel/srt079

Everly, Jr., G.S. \& Lating, J.M., 2019, A clinical guide to the treatment of the human stress response, Springer Science+Business Media, New York, NY.

Geertz, A.W., 2010, 'Brain, body and culture: A biocultural theory of religion' Method \& Theory in the Study of Religion 22(4), 304-321. https://doi.org/ $10.1163 / 157006810 \times 531094$

Gitay, M., 2015, 'The brain frame - From molecules to behaviour', Journal of the Dow University of Health Sciences 9(1), 30-36.

Gomes, F.C., De Andrade, A.G., Izbicki, R., Almeida, A.M. \& De Oliveira, L.G., 2013 'Religion as a protective factor against drug use among Brazilian university students: A national survey', Revista Brasileira de Psiquiatria 35(1), 29-37. https:// doi.org/10.1016/j.rbp.2012.05.010

Hayward, R.D., Owen, A.D., Koenig, H.G., Steffens, D.C. \& Payne, M.E., 2012, 'Longitudinal relationships of religion with posttreatment depression severity in older psychiatric patients: Evidence of direct and indirect effects', Depression Research and Treatment 2012, 1-8. https://doi.org/10.1155/ 2012/745970

Hybels, C.F., George, L.K., Blazer, D.G., Pieper, C.F., Cohen, H.J. \& Koenig, H.G., 2014 'Inflammation and coagulation as mediators in the relationships between religious attendance and functional limitations in older adults', Journal of Aging and Health 26(4), 679-697. https://doi.org/10.1177/0898264314527479

Jackson, M., 2012, 'The pursuit of happiness: The social and scientific origins of Hans Selye's natural philosophy of life', History of the Human Sciences 25(5), 13-29. https://doi.org/10.1177/0952695112468526

Jones, T., 2010, The sacred way: Spiritual practices for everyday life, Zondervan, Grand Rapids, MI.

Jordan, K.D., Masters, K.S., Hooker, S.A., Ruiz, J.M. \& Smith, T.W., 2014, 'An interpersonal approach to religiousness and spirituality: Implications for health and well-being', Journal of Personality 82(5), 418-431. https://doi.org/10.1111/ jopy. 12072

Keil, R.M., 2004 'Coping and stress: A conceptual analysis', Journal of Advanced Nursing 45(6), 659-665. https://doi.org/10.1046/j.1365-2648.2003.02955.x

Kim, Y.T., 2010, 'An understanding of shame and guilt: Psycho-socio-spiritual meaning', Torch Trinity Journal 13(2), 218-232.

Koenig, H.G., 2015, 'Religion, spirituality, and health: A review and update', Advances in Mind-body Medicine 29(3), 19-26. https://doi.org/10.1016/B978-0-12-8112823.00001-X

Krägeloh, C.U., Chai, P.P.M., Shepherd, D. \& Billington, R., 2012, 'How religious coping is used relative to other coping strategies depends on the individual's level of religiosity and spirituality', Journal of Religion and Health 51(4), 1137-1151. https://doi.org/10.1007/s10943-010-9416-x

Krause, N., Ironson, G., Pargament, K. \& Hill, P., 2017, 'Neighborhood conditions, religious coping, and uncontrolled hypertension', Social Science Research 62 161-174. https://doi.org/10.1016/j.ssresearch.2016.08.004

Kronström, K., Salminen, J.K., Hietala, J., Kajander, J., Vahlberg, T., Markkula, J. et al., 2009, 'Does defense style or psychological mindedness predict treatment response in major depression?', Depression and Anxiety 26(7), 689-695. https:// doi.org/10.1002/da.20585

Krumrei, E.J., Pirutinsky, S. \& Rosmarin, D.H., 2013, 'Jewish spirituality, depression, and health: An empirical test of a conceptual framework', International Journal of Behavioural Medicine 20(3), 327-336. https://doi.org/10.1007/s12529-012of Behovic 
Le Roux, S., 2020, 'The body metaphor and spiritual coping within a South African cohort: A pastoral approach', PhD dissertation, Faculty of Theology, North-West University.

Le Roux, S., Lotter, G.A., Steyn, H.S. \& Malan, L., 2018, 'Cultural coping as a risk for depression and hypertension: The SABPA prospective study', Cardiovascular Journal of Africa 29(6), 366-373. https://doi.org/10.5830/CVJA-2018-045

Lioy, D.T., 2010, 'The Garden of Eden as a primordial temple or sacred space for humankind', Conspectus: The Journal of the South African Theological Seminary 10(1), 25-57.

Lloyd-Jones, M., 2009, The Gospel in Genesis: From fig leaves to faith, Crossway Books, Wheaton, IL.

Malan, L. \& Malan, N.T., 2016, 'Emotional stress as a risk for hypertension in subSaharan Africans: Are we ignoring the odds?', in M.S. Islam (ed.), Hypertension: From basic research to clinical practice, advances in experimental medicine and biology, vol. 956, no. 2, pp. 497-510, Springer, Cham.

Mays, J.L., 2011, Psalms: Interpretation: A Bible commentary for teaching and preaching, Westminster John Knox Press, Louisville, KY.

McEwen, B.S. \& Gianaros, P.J., 2010, 'Central role of the brain in stress and adaptation Links to socioeconomic status, health, and disease', Annals of the New York Academy of Sciences 1186(1), 190-222. https://doi.org/10.1111/j.1749-6632. 2009.05331.x

McGrath, A.E., 2020, Science \& religion: A new introduction, John Wiley \& Sons, Hoboken, NJ.

McKeown, J., 2008, Genesis: The two horizons Old Testament commentary, Wm. B. Eerdmans Publishing, Grand Rapids, Ml.

Merriam-Webster, 2017, Cope, viewed 26 August 2020, from https://www.merriamwebster.com/dictionary/cope.

Michael Liedke, D.N.P., 2018, 'Neurophysiological benefits of worship', The Journal of Biblical Foundations of Faith and Learning 3(1), 1-9.

Minatrea, M., 2012, Shaped by God's heart: The passion and practices of missional churches, vol. 1, John Wiley \& Sons, Hoboken, NJ.
Paynter, H., 2019, God of violence yesterday, God of love today?: Wrestling honestly with the Old Testament, Wipf \& Stock Publishers, Eugene, OR.

Pretorius, M., 2011, 'The creation and the fall of Adam and Eve: Literal, symbolic, or myth?', Conspectus: The Journal of the South African Theological Seminary 12(9), 161-184.

Sanaeinasab, H., Saffari, M., Sheykh-Oliya, Z., Khalaji, K., Laluie, A., Al Zaben, F. et al., 2020, 'A spiritual intervention to reduce stress, anxiety and depression in pregnant women: Randomized controlled trial', Health Care for Women International 12 November, 1-18. https://doi.org/10.1080/07399332.2020. 1836643

Schader, J.M., 2013, 'Determining an interpretational framework based on a proposed structure for Psalm 47', Journal for Semitics 22(1), 124-143.

Smither, E.L., 2014, 'Augustine on redemption in Genesis 1-3', Verbum et Ecclesia 35(1), 1-4. https://doi.org/10.4102/ve.v35i1.1315

Speed, D., 2016, "What is spirituality anyway? Is "spirituality" so broadly defined that testing for it is meaningless?', Skeptic Magazine 21(4), 34-36.

Van der Walt, T., 2007, The Messiah has come!: A guide in the Gospels for serious students of the Bible, Potchefstroom Theological Publications, Potchefstroom.

Weber, S.R. \& Pargament, K.I., 2014, 'The role of religion and spirituality in mental health', Current Opinion in Psychiatry 27(5), 358-363. https://doi.org/10.1097/ YCO.0000000000000080

Wen, M., 2014, 'Parental participation in religious services and parent and child well-being: Findings from the national survey of America's families', Journal of Religion and Health 53(5), 1539-1561. https://doi.org/10.1007/s10943-013$9742-\mathrm{x}$

Woods, R.J., 2015, Christian spirituality: God's presence through the ages, Orbis Books, Maryknoll, New York, NY.

Yıldırım, M., Kızılgeçit, M., Seçer, İ., Karabulut, F., Angın, Y., Dağcı, A. et al., 2021. 'Meaning in life, religious coping, and loneliness during the Coronavirus health crisis in Turkey', Journal of Religion and Health 1-15. https://doi.org/10.1007/ s10943-020-01173-7 